\title{
DEVELOPMENT OF ART EDUCATION IN THE YELISAVETGRAD REGION (SE- COND HALF OF XIX - BEGINNING OF XX CENTURY) ACCORDING TO THE DICTIONARY OF «ARTISTS OF STEPPE UKRAINE»
}

\section{Huleikova}

У статті скрізь призму біографій митців, щзо представлені у виданні «Митці Степової України», розглядається розвиток художньої освіти на Єлисаветградщині (другої половини ХІХ - початку ХХ століття). Основним осередком художньої освіти на той час в Слисаветграді були Вечірні рисувальні і креслярські класи, які були засновані П. Крестоносиевим. У словнику на широкій джерельній базі було зібрано та уніфіковано понад 200 статей про митиів та їхніх учнів, щзо перебували колись у степовому краї (Єлисаветградщина в ией період входила до Херсонської губернї̈, нині - територія Кіровоградської області з обласним иентром м. Кропивницький). Акцентується, щзо мистецьке життя на той час розвивалося в загальноєвропейському контексті. Чимало митщів, щуо представлені у словнику, зробили вагомий внесок у мистецтвво не тільки Украӥни, але й інших краӥн світу. У статті також розкриваються особливості роботи над словником: встановлення маловідомих імен - художників-педагогів та їхніх учнів, уточнення біографій вже відомих персоналій. Дослідження біографій надало змогу окреслити відправні точки та шляхи майбутніх пошуків з метою історико-педагогічної реконструкиї стану і динаміки культурно-освітнього процесу в краї, зародження та існування локальної художньої школи та розвитку мистецького процесу в иілому. Саме дослідження сприятиме узагальненню мистецького педагогічного досвіду та популяризачії творчого використання ідей видатних педагогів у сучасних умовах, відіграватиме важливу роль у забезпеченні розвитку наукових досліджень сучасної педагогічної науки, освіти і практики

Ключові слова: словник «Митиі Степової України» педагогічна освіта, педагогічна біографістика, мистеитво, художньо-промислова освіта, навчальні заклади, Вечірні рисувальні і креслярські класи, Слисаветград

Copyright (C) 2020, I. Huleikova. This is an open access article under the CC BY license (http://creativecommons.org/licenses/by/4.0).

\section{Introduction}

The study, generalization and critical rethinking of the experience of training in the field of art and industrial education of the late XIX - early XX century, is of scientific interest today. Many things from the best teaching experience, improving methods, techniques and organization of training can be used to more successfully solve training problems for the art industry, including design. Also an important component of this process is the study of pedagogical personalities, which is one of the priority areas of development of modern historical and pedagogical science, evidence of which is the emergence of numerous studies on well-known and littleknown figures, who contributed to the development of education and pedagogical thought in Ukraine.

One of the links in the study of past educational experience is the study of biographies of artists, who have been educated in certain educational institutions and accordingly, through the study of their way of life we can trace the educational impact, determine the specifics and quality of training. Unfortunately, many names of artists who were born in the Steppe region or worked here for some time have been lost, and their works have not survived or are unknown to scientists. It is to the establishment of these names - artists-teachers and their students, clarification of biographies of already known personalities, historical and pedagogical reconstruction of the educational process in the Yelisavetgrad region the continued work on the dictionary "Artists of steppe Ukraine» was devoted [1]. This became an important source base for further historical and pedagogical research.

\section{Literary review}

Questions of preparation and activity of artiststeachers were considered in scientific research by: T. Vysikailo [2], Z. Hurich [3], T. Panok [4]. The regional aspect of art education development in the South of Ukraine, which included Yelisavetgrad at that time, is presented in the works [5, 6] of L. Rusakova [5], O. Filonenko [6]. Among them is the work of R. Shmagalo [7] that is the most thorough and key for this study, it is in it that the Yelisavetgrad Evening Drawing and Design Classes are defined as an authoritative art school and fit into the context of the development of European art and industry education.

Different aspects of these themes are presented in publications of local researchers. It is necessary to distinguish some special work and publications by V. Bosko [8], special focus is deserved by a series directories «Historical Calendar», which give an information on the art- 
ists of the XIX - early XX century. One of the latter books was the album [9], prepared by the scientific community of the Kirovohrad region Art Museum.

Researches of personalities by foreign scientists, namely artists, who received primary art education in Yelisavetgrad, certify the necessity and the weight of this research, because in their work information about primary education is mentioned only in passing or not at all.

Among them there are: O. Kolyanchuk [10], researched the way of life of Paul Zaporojchenko - a graduate of Yelisavetgrad classes, who executed many paintings of churches in Poland; V. Prishchepova [11], considered the St. Petersburg period of Samuil Dudin's work, which left its mark on Yelisavetgrad's public life; A. Nekrasova [12], described the work of Isidore Zolotarevsky, briefly mentioning Yelisavetgrad; Kirby Tenhulzen [13], created a website, dedicated to the life of Boris Major with numerous documents and information, however there is no information about the art teaching place; Anna Hendzel-Andreew [14], described the creative way of Kazimiera Adamska-Rouba - graduate of Evening drawing and design classes; Murielle Lucie Clément [15], researched the creativity of the pupil of Yelisavetgrad classes Michel Matveev; Meidler-Waks, Sigalit [16], researched the Berlin years of the artist Issachar Ryback, the subject of her master's thesis, and then done her doctorate on his life and work.

\section{The aim and objectives of the study}

The aim of the study was to analyze some aspects of the development of art education in the Yelisavetgrad region. were set:

To achieve this aim, the following objectives

1. To review the publication of the «Dictionary of Artists of Steppe Ukraine» and determine the importance of such research in the context of Ukrainian pedagogical biography.

2. To reveal practical aspects of use and to forecast prospects of research.

\section{Materials and methods}

The documentary materials of the Central State Historical Archives of Ukraine (Kyiv), the Central State Archive of higher authorities and government of Ukraine (Kyiv), State Archive of the Kirovograd region as well as archival manuscripts and scientific collections of phonerecording of Maxim Rylsky Institute of art studies folklore and ethnology (National Academy of Sciences of Ukraine) are the source base of the proposed research. The materials of Vernadsky National Library of Ukraine (Kyiv), the National Parliamentary Library of Ukraine (Kyiv) Regional Library Kirovograd, Odessa, Lviv and Dnipro are enlisted as well. In a dictionary a total involved sources is over 1000 items: including scientific papers, periodicals, documents from various archives of libraries and museums. In the process the author had to work in the funds of art and local history museums in Ukraine and Russia in cities such as Simferopol, Kyiv, Dnipro, Odessa, Lviv, Moscow, Yekaterinburg, Tomsk, to look for different materials in private collections.

At the same time, many materials that today could supplement information about artists of the region are stored outside Ukraine: in Belgium - I. Pohitonova; in Moldova - O. Foynitsky; in Germany - I. Babia; in Poland - G. Bilinska-Bogdanovich, P. Zaporozhchenko, K., Adamska-Rovba; in Russia - P. Krestonostsev, P. Pokarzhevsky, O. Osmerkin; in France, P. Gansky and others.

\section{Results and discussion}

The articles of the dictionary «Artists of the Steppe Ukraine» in alphabetic order consist of four parts: title, biographical part, bibliographical part, the list of works of art and names of establishments where they are remained. The articles briefly describe the life and creative way of artists, give some information about their learning, present characteristics of their styles. In the end of each article there is the base bibliography, indicating the main sources, in which one can find the most complete information about the person. The artists' works (if we know any) are proposed as well. The texts are followed by self-portraits, portraits of an artist, made by other painters or by photos, reproductions of their paintings, some of them are presented for the first time.

The biographical dictionary-guide contains information about painters, sculptors, graphic artists, architects, artists-teachers and researchers of art, whose life and activity are connected with the Yelisavetgrad and Alexandria counties of the Kherson province (now - Kirovograd region). Auxiliary apparatus consists of a nominal index, a list of abbreviations.

Steppe Ukraine - a land with rich artistic traditions, which origins can be found in the seventeenth century and which became a prerequisite for foundation and establishment of the city of Yelisavetgrad (now - Kropyvnytskyi) as an artistic centre for the future.

The countdown of the developing of the artistic process in the region starts at the beginning 1of 750's and is linked with the foundation of the city after the decree of Empress Elizabeth, concerning the building of the fortress in 1751. At that time the main centre of art of the contemporary Ukraine, was the Convent of Pechersk in Kyiv. After a few years a wooden cathedral Trinity Church was erected at the territory of the fortress. In 1754 the iconographer of Convent of the Pechersk Alimpiy Halyk painted three icons for this temple: images of Zechariah - the father of John the Baptist, the Apostles Peter and Paul and St Elizabeth, who was considered as the patroness of the city [17].

In the mid of XIX century the provincial town Elisavetgrad became one of the industrial and cultural centres of the southern Ukraine. This time is marked by the most significant events in artistic life, which was largely associated with the animation of the Provincial movement activities of educational organizations, charitable societies.

In 1880 the alumnus of the Academy of Fine Arts, academician of portrait painting Peter Krestonostsev founded near Yelisavetgrad Zemsky real school Evening drawing and design classes, which have become a great cultural centre and influenced the artistic and educational life, not only of this region, but of the whole Ukraine as well. When in 1893 Mr. Krestonostsev left Yelisavetgrad, his work was continued by his colleagues-teachers, who preferably graduated from the Academy of Fine 
Arts: M. Nikol'skii, A. Olshansky, N. Lebedev, F. Kozachynskiy, A. Pavlov and others [18].

During the activity of the Classes (1880-1918) more than two thousand people graduated from them, among them painters: P. Pokarzhevsky, A. Osmerkin, A. Foynytskiy, P. Ganskiy, A. Lopuhin, I-B. Rubak, S. Dudin, A. Rozumnuy, O. Abbo, K. Adamska-Rouba, B. Major [19]. Y. Constantinowsky, (alias Josef Constant, Michel Matveev), I. Olinskiy, M. Portnoff, A. Galoustchenko, A. Weyzen, A. Hruzhevsky, A. Staborovskyy, P. Kosyura; iconographer P. Zaporozhchenko, N. Nikolenko, and many others. Unfortunately in the literature articles, dealing with creative works of these artists, researchers not always-mention them as persons from the Yelisavethrad region, where they have received their first art education.

In this study let's stop only on some individuals, the initial period of art education, which was not identified in the available literature, however, according to our observations, it became decisive in their further activity.

It is impossible - to circumvent by attention an artist-iconographer Pavlo Zaporizhsky - (Zaporozhchenko), the pupil Evening drawing and design classes, later UNR army soldier. He was must to emigrate to Poland in 1927 in the town of Przemysl, where organized the art studio «Renaissance» together with Boris Paliy Neyil, P. Kovzhun, M. Prasitskiy entered there. The workshop engaged in the conservation and restoration of churches in Galicia and Lemkivshchyna, destroyed during the First World War [10].

In the city of Simferopol in the Museum of Modern Christian Art we can present works by the artist, graduate of the mention Classes - iconographer George Bostrem and this museum is named after him. He is a pupil and a friend of the famous Russian artist V. Kandinsky, who later organized the association group of youth artists, known as «Independent Artists» in Odessa [20].

An extraordinary figure in the artistic life of Yelisavetgrad was a sculptor Isidore Zolotarevskiy. He also received his first artistic skills in the Evening drawing and design classes. Later he continued his arts education at the Paris Academy of Fine Arts. Having returned to his hometown, he opened an art studio here. Later, while he was living in Moscow, his compatriots - A. Osmerkin, A. Nuremberg, A. Rozumhiy often stayed in his house, and they left the memories about his friend. I. Zolotarevskiy is the author of death masks of S. Esenin. We can recognize him in the image of rich «Moscow merchant», made by B. Kustodiev [12]. Another portrait of I. Zolotarevskogo was created by his friend - A. Rozumnuy, who successfully had realized himself as an actor and painter, and later as a writer, director and cinematographer he organized one of the first documentary film studios in Moscow. He took part in making of 20 films, among them «Timur and his team», «The Life and Death of Lieutenant Schmidt», «Miklukho-MacIay», «Mother» and others. His series (over 200 pieces) of graphic portraits of artists and film makers, with whom he worked and communicated, is known.

In the XIX-th - early XX-th century some original and talented architects worked in Yelisavetgrad, among them: Alexander Dostoevsky, a brother of the famous
Russian writer, who used in his designs the style of medieval castle architecture, P. Fedorov - author of «tent» buildings with a variety of small ornaments [21].

Considerable part of buildings, belonging to the historical center of Yelisavetgrad forms the historic architectural image of the city, built with a direct participation of the architect J. Pauchenko. He skilfully used in his design elements of different styles - modern, Moorish, neo-byzantine, neo-classicism. His buildings are executed in chamber character, his virtuoso brickwork and superior metal jewellery are very exquisite. The Yelisavetgrad newspaper "Golos Yuga" wrote in 1914 «The whole series of erected by him buildings is very bright and tells about him as of a talented artist-architect... Undoubtedly, his merit is that he was the first in our city to give examples of art architecture...». The best works of Y. Pauchenko are Weisenberg's house with renaissance and baroque forms, Goldenberg electricity-water-hospital in the Moorish style, St. Anne's Hospital. His own house in the byzantine style - (now A. A. Osmerkin Art Memorial Museum) is recognized as an architectural monument as well [22].

The famous architect A. Lishnevskiy - a graduate of the Academy of Arts was known by his large scale project. Some buildings, designed by him: girls' gymnasium, synagogue, and the most famous building of the city, the house of the former mansion of a merchant Barsky (now Museum) has been preserved [21].

Architects, who were born in Yelisavetgrad later, worked in many cities of the Russian Empire. Architect B. Kornienko, very known in Kharkiv, studied the problem of Ukrainian national style in architecture, with his colleague K. Zhukov presented their projects at exhibitions in Yelisavetgrad and made popular lectures, dedicated to the Ukrainian version of the art modern style.

At the turn of XIX-XX centuries A. Veyzen worked in Sebastopol, where he developed a new general architectural plan of the city and an architectural complex, dedicated to the 50th anniversary of the defence of Sevastopol during the Crimean war, executed in the neo empire style and the style of Classicism [23]. Students of the Evenings drawing and design classes, later graduates of the architectural department of the St. Petersburg Academy of Arts, A. Hrujevskiy and A. Staborovskiy won the all-Russian design competition with their project of the Military Ascension Cathedral in Novocherkassk city [24].

The artistic and educational activities of Evening drawing and design classes in the 1920-1930 were continued by S. Danishevskiy - a graduate of the Academy of Fine Arts (Repin's class). Later on he visited private schools of Julien and Laurent in Paris. After returning in 1912 from France to Yelisavetgrad, S. Danishevskiy organized the painter's studio «Art» and headed a local artindustrial school here at the Art Department «Hudprom». M. Brodsky, P. Brodska, P. Krayc, M. Svitenko, Y. Gorobchenko were his pupils. We should also mention his student G. Sinitsya, which belonged to the group of «Boichukists» and then to «the sixties» [25].

Artistic life of this steppe region developed within the West-European context. Many immigrant artists from the Yelisavetgrad region made a significant contribution into the arts not only in Ukraine, but also in other coun- 
tries. The bright example of this is the creative work of Ivan Pokhitonov. Foreign researchers of his biography believe that he was formed in Ukraine as an artist, observing and sensitive to the nature, and later his talent developed under the influence of French artistsrepresentatives of Barbizon and the impressionist schools. Except the elegance and sophistication of his unique landscapes - «miniature pearls» as said Repin there is something that French people would be call impressionistic melancholy, and Ukrainian people - longing for the ideal. The high professionalism of paintings, executed by him, allowed him to take part in salon exhibitions in Paris, where they were highly appreciated. The inspiration to work was given to I. Pokhitonov by his native land that he regularly visited and painted here the steppe landscape. At the end of his life I. Pokhitonov bequeathed all his creative legacies to Yelisavetgrad, where the art museum was started creating after his initiative (unfortunately, almost all the artistic heritage of the famous Ukrainian artist is now abroad) [26].

In the USA, the names of the natives of the steppe region are well known: the classic of American painting by Ivan Olinsky and the theatrical artist Jacob Wenger [27]. The graduates of the Yelisavetgrad Junker Cavalry College were: the artist Sergei Obrazkov, who left for Yugoslavia in 1921 and worked in California after the Second World War; Viktor Arnautov - later leader of the Modernists in California; Konstantin Podushkin - original master of graphics in the field of postcard; Vladimir Doriani, one of the five most original neo-primitivist artists in America. Lived in France: a politician, writer and artist Vladimir Vinnichenko, neoclassic painter Ivan Babiy, Yuri (Georgy) Dekonski, and follower of drawing classes, Peter Gansky - the author of both picturesque and literary-philosophical works. A graduate of the classes - Isahar-Ber Rybak became one of the organizers of the famous educational organization «Culture League» and theorist of the Jewish avant-garde of the early XX century.

The long-term work on the vocabulary of the «Steppe Art of Ukraine» was devoted to establishing these names - artists-pedagogues and their students, clarification of biographies of already known personalities, historical and pedagogical reconstruction of the educational process in the Yelisavetgrad region.

\section{Conclusions}

Thus, it can be noted, that the development of fine arts in the Yelisavetgrad region was mainly associated with the Evening Drawing Classes at Yelisavetgrad Zemsky Real School, which were founded by P. Krestonostsev and became the main focus of art education. They became the first stage in obtaining art education for about 200 artists, who later became famous.

1. The biographical dictionary-guide provides information about artists-educators and their students painters, sculptors, graphic artists, architects, whose life and activities are related to the steppe region - Yelisavetgrad and Alexandria counties of the Kherson province (now - Kropyvnytskyi) of early XX century. On the basis of museum and archival materials, both already known (with certain updated data) and new names of artists and information about them are introduced into scientific circulation. Specificity of the biographical method can be considered to be its great focus on unique aspects of human life history, sometimes in an organization group, and on a subjective personal approach to describing the human life of the career history and so on. The study of biographies, the comparison of historical facts in the stories, makes it possible to compare the factual version of the historical event and social changes. This opens up additional options for viewing already installed official versions.

2. Materials of the Dictionary of «ARTISTS OF STEPPE UKRAINE» can be used as an auxiliary tool in the study of the disciplines «History of Pedagogy», «History of Art», «Methods of teaching fine arts» and others. They will be useful in the process of mastering the students' knowledge of the formation and development of pedagogical skills of artists-educators and their students, and will be useful to a wide range of researchers: museum staff, art historians, educators, collectors and others.

Therefore, the creation of an information and bibliographic resource «ARTISTS OF STEPPE UKRAINE», which can be replenish and updated, will contribute to the generalization of artistic pedagogical experience and popularize the creative use of ideas of outstanding pedagogues in modern conditions, will play an important role in ensuring the development of scientific research practices, advanced training, continuous self-education.

\section{References}

1. Bosa I. O. Myttsi stepovoi Ukrainy (kintsia XIX - pochatku XX stolittia). Kyiv: IMFE im. M.T.Rylskoho NAN Ukrainy, 2013. 133 p.

2. Vysikailo T. V. Formuvannia fakhovoi kompetentnosti maibutnikh uchyteliv obrazotvorchoho mystetstva u protsesi plenernoi praktyky: PhD thesis. Poltava, 2017. 243 p.

3. Hurich Z. V. Rozvytok khudozhnoi osvity v pochatkovykh ta serednikh navchalnykh zakladakh Khersonskoi hubernii (druha polovyna XIX - pochatok XX st.): abstract PhD thesis. Kyiv, 2017. 21 p.

4. Panok T. V. Teoretychni i metodychni zasady pidhotovky maibutnikh khudozhnykiv-pedahohiv u konteksti rozvytku vyshchoi khudozhnoi osvity Ukrainy (1917-1991 rr.): abstract doctors thesis. Kyiv, 2017. 40 p.

5. Rusakova L. I. Rozvytok pryvatnoi khudozhnoi osvity v Ukraini (druha polovyna XIX - pochatok XX stolittia): abstract $\mathrm{PhD}$ thesis. Kropyvnytskyi, 2017. 20 p.

6. Filonenko O. V. Osvita Kirovohradshchyny (Yelysavethradshchyny) v naukovykh refleksiiakh ukrainskykh uchenykh (druha polovyna XIX - XX stolittia): monograph. Kharkiv: Machulyn, 2017. 412 p.

7. Shmahalo R. T. Mystetska osvita v Ukraini ser. XIX - ser. XX stolittia: strukturuvannia, metodolohiia, khudozhni pozytsii. Lviv, 2005. $528 \mathrm{~s}$.

8. Bosko V. Vyznachni postati stepovoi Ellady. Kirovohrad: Inf. merezha, 2004. 376 p.

9. Obrazotvorche mystetstvo (mynule i suchasne): album. Kirovohrad, 2008. 312 p. 
10. Kolianchuk O. Pavlo Zaporizhskyi - artyst- maliar z Velykoi Ukrainy ta yoho pravoslavni spivvitchyznyky. Tserkovnyi Kalendar, 2005. P. 217-225.

11. Prischepova V. A. K 150-letiiu so dnia rozhdeniia S. M. Dudina - khudozhnika, etnografa (po materialam MAE RAN) // Antropologicheskii forum. 2011. Issue 15. P. 608-649.

12. Nekrasova A. N. I. S. Zolotarevskii i khudozhestvenno-reprodukcionnaia masterskaia Glavnauki // Voprosy muzeologii. 2015. Issue 1 (11). P. 12-20.

13. Searching for boris major. URL: https://sites.google.com/site/borismajorartist/home (Last accessed: 9.07.2020)

14. Hendzel-Andreew A. W „Dzienniku” Ferdynanda Ruszczyca o Ludomirze Sleńdzińskim // Ananke. 2000. Issue 2-3. P. 24-25.

15. Murielle Lucie Clément (Hrsg.). Raffaele Zanotti: Le Son de l'Est de Michel Matveev // Écrivains Franco-russes. Amsterdam, 2008. P. 59-68.

16. Meidler-Waks Sigalit. Issachar Ber Ryback. Leipzig: Hentrich \& Hentrich, 2019. 369 p.

17. Zholtovskyi P. M. Khudozhnie zhyttia na Ukraini v XVI - XVIII stolittiakh. Kyiv, 1983. 120 p. 1895. $897 \mathrm{p}$.

18. Sistematicheskii svod postanovlenii Elisavetgradskogo Uezdnogo Zemskogo Sobraniia 1888-1895 gg. Elisavetgrad, oblasti.

19. Vedomosty uspevaemosty uchashchykhsia. 1887 hh. F. 60. Op. 1. Spr. 65.222 ark. Derzhavnyi arkhiv Kirovohradskoi

20. Barkovskaia O. M. Zhitie Georgiia Bostrema // Deribasovskaia - Rishelevskaia. 2010. Issue 40. P. 263-280.

21. Kyrychenko O. Stylovi poshuky arkhitektora Oleksandra Lishnevskoho v yelysavethradskyi period tvorchosti (18951901 roky) // Ukrainske mystetstvoznavstvo. Materialy, doslidzhennia, retsenzii. 2009. Issue 9. P. 218-223.

22. Nadiezhdin A. Yakiv Pauchenko - arkhitektor Yelysavethrada // Materialy oblasnoi kraieznavchoi konferentsii: Kulturno-osvitni protsesy kraiu u XIX. Kirovohrad, 2004. P. 95-102.

23. Sokol K. G. Monumentalnye pamiatniki Rossiiskoi imperii: katalog. Moscow: Vagrius Plius, 2006. 432 p. oblasti.

24. Vedomosty uspevaemosty uchashchykhsia. 1887 hh. F. 60. Op. 1. Spr. 65.222 ark. Derzhavnyi arkhiv Kirovohradskoi

25. Ot komiteta po ustroistvu khudozhestvennoi vystavki v Elisavetgrade // Golos Iuga. 1913. 4 p.

26. Bertrand O. Ivan Pokhitonov (1850-1932) // Catalogue Raisonné. Vol. 1. Luxembourg: Belart International Editions, 2015. P. 155.

27. Wenger Steps from Films to Watercolor // Art Digest. 1935. Vol. 10. P. 6.

Received date 08.06.2020

Accepted date 22.06.2020

Published date 31.07.2020

Iryna Huleikova, Head of Department, Research Department on Books and Printing History of the X-XXI centuries, Museum of Books and Printing in Ukraine, Lavrska str., 9, Kyiv, Ukraine, 01015

E-mail: 1s201@ukr.net 